\title{
THE FUTURE OF AUTOMATIC TAX INFORMATION EXCHANGE IN EU COUNTRIES
}

\author{
Alicja Brodzka*
}

\begin{abstract}
Tackling the issue of tax revenue losses starts to be the highest priority for developed countries. In the attempts to protect the national tax bases and to fight harmful tax competition, the whole world starts to give the extra weight to the principles of fiscal transparency and information exchange, addressing them on international agendas. Also the European governments are seeking to recover their missing billions of taxes. The article focuses on the main issues connected with transparency and exchange of tax information. It brings closer the internationally agreed standard of exchange of information for tax purposes and shortly presents the modes of tax information exchange. Next the study turns to the European Union's perspective. It analyzes the legal framework of automatic tax information exchange within the EU and presents the influence of the U.S. FATCA on the EU legal environment. It also tries to answer the question whether creating the international tax information exchange system, based on automatic transfer of data, could be possible in the future.
\end{abstract}

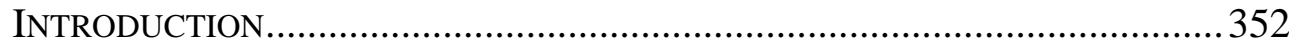

I. TRANSPARENCY AND EXCHANGE OF TAX INFORMATION..........................353

A. The Standard of Exchange of Information for Tax Purposes ... 354

B. The Modes of Tax Information Exchange............................... 355

II. EUROPEAN UNION AND THE TAX INFORMATION EXCHANGE ...................356

A. The Automatic Exchange of Information ............................... 356

B. The Administrative Cooperation among EU Member States ...358

C. The Influence of FATCA .................................................. 359

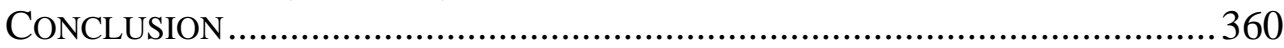

\section{INTRODUCTION}

Tackling the issue of tax revenue losses starts to be a highest priority for developed countries. In the attempts to protect the national tax bases and to tackle harmful tax competition, the whole world starts to give the extra weight to the principles of tax transparency and information exchange, addressing them on international agendas.

Also the European governments are seeking to recover their missing

\footnotetext{
* Dr., Assistant professor at the Wroclaw University of Economics, Poland. Research fields: International Taxation, Tax Information Exchange, Tax Havens, Harmful Tax Competition and Good Tax Governance.
} 
billions of taxes, as the estimates show that tax evasion and avoidance might cost them 1 trillion EUR a year ${ }^{1}$. Tax frauds and tax evasion restrict the States' ability to increase revenues and to implement effectively the economic policy. Billions of Euros kept offshore-often undeclared and untaxed-significantly reduce the national tax bases of developed countries. Decisive action to reduce tax fraud and tax evasion could bring public budgets across Europe with significant growth in tax revenue size.

The article presents the main issues connected with transparency and exchange of tax information, seen from European Union's perspective. It brings closer the internationally agreed standard of exchange of information for tax purposes and shortly presents the modes of tax information exchange. Analyzing the legal framework within the EU and next, the influence of the U.S. Foreign Account Tax Compliance Act (FATCA), allows to describe the EU legal environment for automatic exchange of information for tax purposes. As introducing the effective system of tax information exchange between sovereign countries, characterized by various legal systems, is not an easy task, the article also considers the problematic issues connected with the process of international exchange of taxation data. It also tries to answer the question whether creating the international tax information exchange system, based on automatic transfer of data, can be possible in the future.

\section{TRANSPARENCY AND EXCHANGE OF TAX INFORMATION}

Exchange of tax information, as the actual data sharing between States that are compliant with transparency, is a non-fiscal measure aimed at curbing tax bases erosion. The whole process serves some practical purposes for tax administrations. The information received can be used to ascertain facts in relation to income and capital of tax treaty partner. It may also assist the country in administrating and/or enforcing its own domestic laws, thus reducing international tax evasion. Additionally, the exchange of information serves as a mechanism that enables tax authorities to solicit cooperation from foreign governments and more effectively prosecute tax and related white-collar crimes ${ }^{2}$.

The efforts made by international organizations to develop norms and guidelines in the field of exchanging tax information and enhancing fiscal transparency have been reflected very well in the initiative launched within

\footnotetext{
${ }^{1}$ R. Murphy, Closing the European Gap, A Report for Group of the Progressive Alliance of Socialists \& Democrats in the European Parliament, Tax Research LLP 2 (2012).

${ }^{2}$ A. Brodzka, S. Garufi, The Era of Exchange of Information and Fiscal Transparency: The Use of Soft Law Instruments and the Enhancement of Good Governance in Tax Matters, 52 EUROPEAN TAXATION, IBFD 397 (2012).
} 
the Global Forum on Transparency and Exchange of Information for Tax Purposes. The Global Forum is the multilateral framework of 124 countries, both OECD and non-OECD ones, within which the work in the area of transparency and exchange of information has been carried out. Through an in-depth peer review process, the Global Forum monitors that its members fully implement the internationally agreed standard of transparency and exchange of information they have committed to implement. The Global Forum also works to establish a level playing field, even among countries that have not joined the Global Forum.

\section{A. The Standard of Exchange of Information for Tax Purposes}

The Global Forum on Transparency and Exchange of Information for Tax Purposes has been a driving force behind the development of the standard of transparency and exchange of fiscal information. The Standard, which is nowadays widely recognized, requires: (1) the existence of mechanisms for exchange of information upon request (in cases when it is "foreseeably relevant" to the administration and enforcement of the domestic laws of the treaty partner); (2) the availability of reliable information (in particular bank, ownership, identity and accounting information) and powers to obtain and provide such information in response to a specific request in a timely manner; (3) the respect for safeguards and limitations and strict confidentiality rules for information exchanged.

The standard of transparency and exchange of information was further broken down into 10 essential elements. In the field of the availability of information: (a) Jurisdictions should ensure that ownership and identity information for all relevant entities and arrangements is available to their competent authorities; (b) Jurisdictions should ensure that reliable accounting records are kept for all relevant entities and arrangements; and (c) Banking information should be available for all account-holders. In the field of the access to information: (a) Competent authorities should have the power to obtain and provide information that is the subject of a request under an EOI agreement from any person within their territorial jurisdiction who is in possession or control of such information; and (b) The rights and safeguards that apply to persons in the requested jurisdiction should be compatible with effective exchange of information. In the field of the exchange of information: (a) Exchange of information mechanisms should provide for effective exchange of information; (b) The jurisdictions' network of information exchange mechanisms should cover all relevant partners; (c) The jurisdictions' mechanisms for exchange of information 


\section{AUTOMATIC TAX INFORMATION EXCHANGE 355}

should have adequate provisions to ensure the confidentiality of information received; (d) The exchange of information mechanisms should respect the rights and safeguards of taxpayers and third parties; and (e) The jurisdiction should provide information under its network of agreements in a timely manner ${ }^{3}$.

The international standard, endorsed by the G20 Finance Ministers in 2004 and by the UN Committee of Experts on International Cooperation in Tax Matters in 2008, started to serve as a model for the vast majority of bilateral tax conventions and tax information exchange agreements. Also all 124 jurisdictions have committed, within the Global Forum, to comply with the standards of fiscal transparency and to implement these in their tax systems, both at a national level and in international relations.

What is important, the Global Forum recognizes as the international standard the "on request" mode of tax information exchange, where the information is foreseeably relevant for the administration or assessment of the taxes of the requesting party, regardless of bank secrecy or a domestic tax interest. For the last five years, after 150 peer reviews of jurisdictions, 105 jurisdictions have assessed the compliance with the international standard of Exchange of Information on request (as well as through education and assistance activities).

\section{B. The Modes of Tax Information Exchange}

The standard of tax information exchange, presented above, has gained international acceptance and nowadays serves as a model in trans-national tax relations. However, the tax information exchange on request is not the only way of transferring tax data between sovereign States, as the data transfer may be based on one of three procedures: (1) exchange of information upon request; (2) spontaneous exchange of information; and (3) automatic exchange of information.

Under the "upon request" procedure, one government (Requesting State), which has difficulties in gathering the tax information about its taxpayer, requests information from another government (Requested State). This procedure is normally effective only if the Requesting State presents a sufficiently detailed request (e.g. the name and location of the bank or other financial institution where the taxpayer has a bank account) and if the Requested State can obtain the relevant information.

The spontaneous exchange of information takes place when one

\footnotetext{
${ }^{3}$ OECD, Tax Transparency 2012 Report on Progress, Global Forum on Transparency and Exchange of Information for Tax Purposes 50 (2012).
} 
government (Transmitting State) has information which it believes would be of interest to the other government and-as a consequence-it spontaneously provides such information to the other government (Receiving State). This kind of information exchange occurs rather rarely and has a limited scope ${ }^{4}$.

The automatic exchange of information involves the systematic and periodic transmission of "bulk" taxpayer information by the source country to the residence country concerning various categories of income (e.g. dividends, interest, royalties, salaries, pensions, etc.). It can provide timely information on non-compliance where tax has been evaded either on an investment return or the underlying capital sum even where tax administrations have had no previous indications of non-compliance. The automatic exchange of information could be the most productive type of exchange of information, but its complexity makes it the most difficult type of exchange of information to implement.

\section{EUROPEAN UNION AND THE TAX INFORMATION EXCHANGE}

European Union, being an active member of the Global Forum, does not limit its scope only to the actions within the Forum, which focuses on the "on request" mode. It rather aims at implementing the automatic exchange of information as a standard in its whole territory (and further, in relations with third countries). As the result, the European Union uses not only the exchange of information on request, foreseen in the wide net of double tax treaties, tax information exchange agreements and the Multilateral Convention on Mutual Administrative Assistance in Tax Matters, but also the automatic exchange based on European Directives.

\section{A. The Automatic Exchange of Information}

The automatic exchange of information was first introduced in 2005, through so-called European Savings Directive (2003/48/EC). Under this Directive, the automatic data transfer between EU Member States takes place in case of interest payments paid by paying agents to EU individual residents, keeping their savings in other Member State. Belgium, Austria and Luxembourg have been allowed, for a transitional period, to apply a withholding tax instead of engaging in the automatic exchange of information on savings. Currently, the rate of this withholding tax is $35 \%$.

\footnotetext{
${ }^{4}$ D. Spencer, Exchange of Tax Information, 5(1) AcCountancy Business AND the PuBlic InTEREST 92 (2006).
} 


\section{AUTOMATIC TAX INFORMATION EXCHANGE 357}

The automatic exchange of information takes place also between EU Member States and third countries, based on special commitments. Such bilateral agreements were signed with the dependent territories of the Netherlands and the Great Britain (Netherlands Antilles, Aruba, Anguilla, Cayman Islands, Montserrat, Turks and Caicos Islands, British Virgin Islands, Isle of Man, Guernsey and Jersey), and with European tax havens (Switzerland, Monaco and Andorra). Third countries in most cases choose the withholding tax instead of automating reporting on interest derived from individuals' savings.

The effect of the Directive is, however, very moderate. In 2010, the interest payments totaling 11.4 billion EUR were subject to exchange of information between national tax authorities in the European Union. A further 504.8 million EUR in withholding tax was paid to the Member States of residence of beneficial owners by certain Member States and third countries which levy a withholding tax rather than exchanging the information $^{5}$. These numbers are not too overwhelming. Nothing strange, the Directive is considered as the law which is easy to circumvent due to many loopholes. In 2008 the European Commission tried to solve the problem and adopted a proposal to amend the European Savings Directive, which would close the existing loopholes by extending information sharing to trusts, pensions, investment funds and "other innovative financial instruments". However, due to the lack of the unanimity among Member States, the proposal of the Directive's amendment has been blocked.

Also the perspectives to significantly expand the geographic scope of the Directives are not too good. Although Belgium quit the transitional regime in 2011 and Luxembourg announced that, starting from 2015, it will set up an automatic exchange of information, the Austria is not eager to shift to automatic exchange regime. As long as Austria refuses to implement the automatic exchange of information, the third countries will be eligible to use the transitional period as well, based on the "level playing field" principle. As a consequence, the automatic exchange of information system will not expand further till the abandonment of the transitional solution by the last EU Member State.

Regardless of the European Savings Directive, the automatic exchange of information will be widened soon, as the provisions of the Mutual Assistance Directive (2011/16/EU) come into force. From Jan. 1, 2015, the automatic exchange of information is to take place on five further categories of income and capital, based on available information. Under the scope of

\footnotetext{
${ }^{5}$ E. M. Poptcheva, A FATCA for the EU? Data Protection Aspects of Automatic Exchange of Bank Information, Library Briefing of the European Parliament 2 (May 27, 2013).
} 
the Mutual Assistance Directive will fall: income from employment, director's fees, life insurance products (not covered by other Directives), pensions, income from immovable property. This list may be also extended to dividends, capital gains and royalties.

\section{B. The Administrative Cooperation among EU Member States}

For developing the cooperation of EU tax authorities, the most important is the above mentioned Mutual Assistance Directive on administrative cooperation in the field of taxation (2011/16/EU) and the Recovery Assistance Directive (2010/24/EU). Their transposition to the national legislation will introduce a number of facilities for EU tax authorities. Tax inspectors from one Member State will be able to work with tax offices of other Member States. The tax control and the exchange of information on taxpayers from other EU countries will be extended. The exchange of information will include a wider range of taxes than before (also at the local level) and will apply to "any information that may be foreseeably relevant to the application and enforcement of rules related to taxes as the sources of state and local revenues".

The exchange of information is to occur by means of electronic communication. Tax authorities will be able to deliver letters abroad to those taxpayers that evade paying taxes in their country. Delivery of the notification with the help of tax administration of another EU Member State will take place only if the first tax authorities are not able to deliver the letter themselves. Officials will be able to receive copies of documents containing information relating to simultaneous proceedings conducted abroad. Moreover, the measures taken by at least two EU countries can result in informing the tax authorities of other States offering them to participate in international audits.

The changes will also be made in the field of simultaneous controls. To initiate and conduct simultaneous controls, it will be enough to make the arrangements and the decision to proceed with a particular control. In practice, it will facilitate the simultaneous audits of companies belonging to the same group and operating in different countries (for instance in the transfer pricing area). These changes will significantly strengthen the flow of tax data, facilitate the tax collection process and reduce the risk of tax fraud and tax evasion ${ }^{6}$.

\footnotetext{
${ }^{6}$ M. Pogroszewska, Fiskusy podziela się danymi, RzECZPOSPOLITA (Apr. 13, 2012).
} 


\section{The Influence of FATCA}

The European Union's legal environment is also being influenced by international trends. One of them is FATCA, the last development of American legislation. Enacted by the US Congress in 2010, FATCA was intended to help the US Internal Revenue Service gather information about Americans' accounts with more than 50,000 USD in assets in foreign banks and other institutions. Scheduled to take effect in 2013, the new law requires that banks and financial institutions worldwide gather the information and disclose it to the US tax collection agency. The penalty for failure to comply with this requirement will be $30 \%$ tax on capital flows from the United States. The new law caused a lot of discussions among third countries, also in the European Union. The European Union pointed that while the US motivation seems to be reasonable, the new legislation will also impose burdensome due-diligence, information reporting and withholding obligations on all foreign (non-US) financial institutions (FFIs). It also raised legal concerns-notably data protection issues ${ }^{7}$.

After complaints from both international environment and the global financial industry about costs and legal issues, the US Treasury announced a new multilateral approach to implementing the Foreign Account Tax Compliance Act. The Treasury proposed the "new government-togovernment framework" which would allow create means to collect the information from FFIs and to send the data to the United States without the necessity to enter into separate data disclosure agreements with the IRS.

The European Commission welcomed the US' shift to the governmentto-government approach to tackling tax evaders and implementing FATCA provisions. As a consequence in February 2012, after the announcement of the American proposals, five EU countries-France, Spain, Germany, Great Britain and Italy — signed the declaration of taking joint action on FATCA towards implementing the intergovernmental approach. Those countries agreed to collect the clients' account information from financial institutions located at their territories and then pass it on to the US tax authorities on the behalf of FFIs, on reciprocal basis. As a consequence, calls have emerged to establish a similar instrument for information exchange among EU Member States and later also with third countries. On April 12, 2013, at the meeting of the European Union's finance ministers in Dublin, France, Great Britain, Italy, Poland, Spain and Germany presented a new initiative against tax evasion and tax avoidance. They announced their intention to exchange

\footnotetext{
${ }^{7}$ A. Brodzka, The Road to FATCA in European Union, 53(10) EuROPEAN TAXATION, IBFD 517 (2013).
} 
FATCA type information amongst themselves-in addition to exchanging information with the United States. In the future, the six countries plan to automatically exchange all relevant data on capital income with each other. That will enable fiscal authorities to collect taxes more easily from taxpayers who invest money in the $\mathrm{EU}^{8}$.

\section{CONCLUSION}

Transparency and exchange of information for tax purposes are one of the hottest topics in the current international agenda. The combination of these two, embedded in the international standard mentioned above, is considered as the best instrument to combat money laundering and to prevent tax avoidance and tax evasion phenomena. The recent years' international initiatives gave the tax administrations unparalleled access to the tax information. In European Union, it is not only the exchange of information (on request and spontaneous), foreseen in double tax treaties, tax information exchange agreements and the Multilateral Convention on Mutual Administrative Assistance in Tax Matters, but also the cooperation based on the Mutual Assistance Directive, the Recovery Assistance Directive and Savings Directive. Further enhancing the administrative cooperation, promoting the use of simultaneous controls and the presence of foreign officials for audits can be also a next step enabling changes and moving tax administrations of EU Member States from just cooperation to tax coordination.

Also the FATCA standard, implemented at the EU level, could be of great help, especially in the light of difficulties with amendments to the EU Savings Tax Directive, caused by the resistance of some Member States. It would also widen the scope of automatic exchange of information, foreseen in the Mutual Assistance Directive-which implements the automatic exchange of information of five types of income and only in case when the information is "available". In particular the intergovernmental agreements between the US and EU Member States can be the catalyst for the drive towards greater transparency. Exchange of information in new categories would be mandatory, as Member States would be making that information available to the US under the FATCA. The "most favored nation" principle stating that Member States must provide EU countries with the same level of information as they provide to third countries, would build the platform to further development in this field. As a consequence, the fact that certain

\footnotetext{
${ }^{8}$ J. O’Donnell and J. Strupczewski, Six Largest Members Agree to Fight Tax Havens, Reuters (Apr. 12, 2013).
} 


\section{AUTOMATIC TAX INFORMATION EXCHANGE 361}

Member States exchange the information with the US can result in those States being required to share the same information within the European Union. As mentioned above, in April 2013, the Great Britain, France, Germany, Poland, Italy and Spain agreed to a pilot initiative in which they would automatically exchange the same information between themselves as with the US under FATCA. Since then 12 other Member States had indicated their wish to join the agreement. According to the Commission, such EU-wide proposal would "avoid a patchwork of different bilateral agreements", preventing loopholes and additional administrative costs ${ }^{9}$.

The next consequence was seen on June 13, 2013, when the EU Tax Commissioner Algirdas Šemeta presented a Proposal for a Council Directive amending the Mutual Assistance Directive ${ }^{10}$, intended to combat tax evasion by expanding the scope of the automatic exchange of information on "dividends, capital gains, all other financial income and account balances". While the five categories of income already covered by the Directive shall only be subject to the automatic exchange if the information is "available", this exception should not apply to the new categories, where the automatic exchange should take place-as Member States will already be making that information available to the USA (under their agreements with the US on the FATCA). Such an enhanced automatic exchange of information would result in the EU having the most comprehensive tax information system and is intended to set the global standard for other nations to adopt in the future.

In order to be effective, transparency and exchange of information would require a constant cooperation between tax authorities on an automatic and spontaneous basis and provision of feedback on results. It goes beyond the national dimension of States and requires enhanced and effective cooperation in developing tax policies at the international level. So-called "FATCA standard" could also contribute to promoting a single approach at a global level to reporting arrangements on financial institutions. The initiatives gain much broader perspective by aiming at the stronger international cooperation, engaging third states into the process of implementing commitments to greater transparency and exchange of information and stressing the need of antifraud agreements with certain jurisdictions. The wide-reaching impact of the new US regime could in the future help in developing a multilateral system of automatic exchange of tax

\footnotetext{
${ }^{9} \mathrm{EU}$ proposes extending automatic tax information exchange to dividends and capital gains, www.out-law.com (June 14, 2013).

${ }^{10}$ Proposal for a council directive amending directive 2011/16/EU as regards mandatory automatic exchange of information in the field of taxation, Brussels, COM(2013) 348 final (June 12, 2013).
} 
information, broader than the automatic information reporting to the United States and among EU Member States.

Recent months have also witnessed the interesting change in the position of OECD. A new OECD report "A Step Change in Tax Transparency”, released in June 2013, outlines steps needed to put in place a global, secure and cost effective model of automatic exchange of information. It also follows the G20 Finance Minister's endorsement in April 2013 of automatic exchange of information for tax purposes as the expected new standard. According to the report, as tax evasion is a global issue, the model needs to have worldwide reach to avoid merely relocating the problem elsewhere. The process also needs to be standardized in order to minimize costs for businesses and governments and to improve effectiveness. The four necessary steps are: (1) enacting broad framework legislation to facilitate the expansion of a country's network of partner jurisdictions; (2) selecting the legal basis for the exchange of information; (3) adapting the scope of reporting and due diligence requirements and coordinating guidance, and (4) developing common or compatible IT standards ${ }^{11}$.

The OECD Report also stresses that more and more jurisdictions are joining the Convention on Mutual Administrative Assistance in Tax Matters, which provides a legal basis for automatic exchange of information. The growth of significance of the convention can add the multilateral dimension to the discussion on transparency and the exchange of tax information, also by the Convention replacing bilateral agreements in the future.

OECD underlines the growing role Global Forum on Transparency and Exchange of Information for Tax Purposes. In 2014 the Global Forum has, in addition to its peer review activities, been laying the foundations for achieving the next level in tax transparency. Apart from the plans of the revision of the international standard of exchange of information on request, the Forum has been mandated to monitor implementation of the new standard-on Automatic Exchange of Information. If a large number of Global Forum members decide to deepen their cooperation in tax matters by committing to implement, this will mean a fundamental change in the global architecture for exchange of information. The Global Forum will have to put in place the mechanisms needed to allow members to indicate their commitment to this new standard and to monitor its implementation ${ }^{12}$.

\footnotetext{
${ }^{11}$ OECD, A Step Change in Tax Transparency, OECD Report for the G8 Summit (June 2013).

${ }^{12}$ OECD, Tax Transparency 2014, Report on Progress, Global Forum on Transparency and Exchange of Information for Tax Purposes 7 (2014).
} 


\section{AUTOMATIC TAX INFORMATION EXCHANGE 363}

The number of initiatives at the national and international level shows that the shift towards fiscal transparency and information exchange is a permanent and significant trend. Measures taken by countries and international organizations allow supposing that the automatic exchange of information can become a standard not only within EU Member States, and in EU-US relations but-in the future-also for the global environment. 